\title{
Climate change impacts on irrigated agriculture in the Guadiana river basin (Portugal)
}

\author{
Pedro Valverde ${ }^{\mathrm{a}, \mathrm{b}}$, Ricardo Serralheiro ${ }^{\mathrm{b}, *}$, Mário de Carvalho ${ }^{\mathrm{b}}$, Rodrigo Maia ${ }^{\mathrm{c}}$, \\ Bruno Oliveira ${ }^{\mathrm{a}, \mathrm{c}}$, Vanessa Ramos ${ }^{\mathrm{a}, \mathrm{c}}$ \\ a Grant Researcher, Project FCT-PTDC/AAC-AMB/115587/09, Portugal \\ ${ }^{\mathrm{b}}$ ICAAM, Institute of Agricultural and Environmental Sciences, University of Évora, Portugal \\ ${ }^{\mathrm{c}}$ FEUP, Engineering Faculty, University of Porto, Portugal
}

\section{A R T I C L E I N F O}

\section{Article history:}

Received 23 July 2014

Accepted 20 December 2014

Available online 7 January 2015

\section{Keywords:}

Climate change

Irrigated agriculture

Agricultural scenarios

Crop water requirements

Guadiana river basin

\begin{abstract}
A B S T R A C T
This study evaluates climate change potential impacts on irrigated agriculture in the Guadiana river basin, in the south of Portugal, by running long-term soil water balance simulations using the ISAREG model and taking into consideration the maximum potential yield. The ISAREG simulations were focused in a set of the most locally representative crops to assess the evolution of net and total water requirements, considering a monthly time step for two 30-year future periods, (2011-2040) and (2041-2070). Reference evapotranspiration was estimated using the temperature-based Hargreaves-Samani equation, and the simulations were performed using, as inputs, a combination of five climate change scenarios built using the Ensemble-Delta technique from CMIP3 climate projections datasets to set different alternative climate change bracketing conditions for rainfall and air temperature. Water balance outputs for different climate scenarios were combined with four agricultural scenarios allowing for the estimation of total irrigation requirements.

A general increase in crop irrigation requirements was estimated, mainly for those crops as maize, pasture, and orchards that are already big irrigation water consumers. Crops as olive groves and vineyards, well adapted to the Mediterranean conditions, show less sensitivity to climate change. The combined results of crop irrigation requirements for climate change and agricultural scenarios allow for the expectation of sustainability for the agricultural scenarios A and C, essentially defined by the complete use of the irrigation network and systems currently being constructed with the Alqueva project, but not for the ambitious irrigation area expanding scenario $\mathrm{B}$.
\end{abstract}

(c) 2014 Elsevier B.V. All rights reserved.

\section{Introduction}

The Guadiana river basin, situated in southern Portugal, with a rich and diversified natural patrimony, presents important potential vulnerabilities in terms of physical and human desertification. In the Guadiana river basin region, socio-economic development has been, traditionally, highly dependent on the agricultural sector due to the lack of other valuable natural resources. Climate change and its related environmental local impacts are likely to be high, specifically in the agricultural and irrigation water availability domains.

Climate change has become universally recognized, based on scientific results backed by historically observed data, and also

\footnotetext{
* Corresponding author. Tel.: +351 266967009.

E-mail address: ricardo@uevora.pt (R. Serralheiro).
}

acknowledged by public perception in the last decades. Institutions like the Intergovernmental Panel on Climate Change (IPCC, 2014) and the European Environment Agency (EEA, 2012) have regularly reported works on observed and future climatic change and respective impacts and risks, and also mitigation and adaptation measures as policy requirements for a sustainable development. Climate change was already a strong concern in the Medalus project (Mairota et al., 1998). Within this project, Corte-Real et al. (1998) noted that "the Mediterranean is one of the areas where the impacts of climate change may be particularly severe" and that "a general decrease in rainfall for the western-central Mediterranean region in recent decades has been reported". The same authors observe that during the three decade period 1961-1990 rainfall has decreased sharply in March, reflecting in spring totals $23 \%$ less rainfall in the case of the Alentejo region, "with a detrimental effect on the growth of cereal crops". 
Within the same project Goodess et al. (1998) estimated future climates using GCM models with increasing $\mathrm{CO}_{2}$ contents in the atmosphere, coupled with statistical models for sub-grid scale results, compensating for the large $(300 \mathrm{~km})$ grid elements typical to GCM models. These authors conclude that "effects on agriculture, for example, may be better described by looking at changes in the availability of water for crop growth". For the same authors, potential evapotranspiration (ETo) cannot be estimated from GCM. "Rather more confidence can be placed in GCM estimates of temperature, which can be related to ETo by an empirical formula...".

One of the remarkable aspects of climate change over the Mediterranean region is the increasing frequency of extreme climatic events as droughts. A recent example of a drought event occurrence was in the hydrological year of 2004/2005, one of the most severe and spatially extensive on record in Portugal (Botelho and Ganho, 2010). More recently, within the first 5 months of 2012, the Portuguese territory experienced a situation of severe drought due to low rainfall in the winter months, inspiring public and governmental concerns on climate change.

One of the most complete reports on climate change in Portugal, SIAM II (Santos and Miranda, 2006), underlines that the 6 warmest years in the period between 1931 and 2000 occurred in the last 12 years of the twentieth century. The SIAM II report also performed a thorough and relevant climate change characterization in Portugal, confirming the rising trends of mean air temperature and decreasing rainfall. Within the project SIAM II, Cunha et al. (2006), reporting on climate change impacts on water resources availability, concluded that "the tendency for reduction both on surface and groundwater is evident, especially in the centre and south regions of Portugal, with increasing non-symmetric distribution during the year, the rainfall concentrating in winter and reducing in spring, summer and fall. The same authors conclude that flow reduction in the rivers of south Portugal and Spain should deserve a particular attention on the strategy for adapting to climate change.

Other authors within the same project (Pinto et al., 2006) referring specifically to climate change impacts on Portuguese agriculture, used GCM (large scale) and regional (intermediate scale) climate change models and the FAO CERES models for crop yields. These authors conclude that drastic reduction on yields is predicted for crops like wheat and maize (up to 50\% loss), and even more (up to $75 \%$ ) for rice. Pasture and fodder crops are the only group of crops that may increase yields (up to 75\%) on the future.

Within the present project, Valverde et al. (2014) analysing the CC impacts on crop yields over the Guadiana river basin during the historical period 1960-2010, observed similar in sense but less in absolute values tendencies for decreasing crop yields due to decreasing rainfall and increasing irregularity of precipitation and the values of temperature.

For the Guadalquivir basin in south Spain, next to the Guadiana basin, Rodríguez Díaz et al. (2007) in a study of climate change impacts on future crop irrigation requirements, stated that “... climate change threatens to exacerbate the current supply-demand imbalance" and modelled an increase in irrigation water requirements between 15 and $20 \%$ by the year 2050 .

The consequences of global warming impacts on agriculture, water resources management and ecosystems pose particular concern in the Mediterranean climates in the transition zone between the arid climate of North Africa and the temperate climate of central Europe. The Mediterranean region, characterized by desert-climate transition features is potentially highly vulnerable to existing adverse trends of warming and rainfall reduction and will likely be the region within Europe to firstly experience severe economical and sociological consequences from climate change. Management and allocation of water are thus particularly sensitive issues in the local agricultural context.
The Alqueva dam is one of the biggest dams and the largest artificial lake $\left(250 \mathrm{~km}^{2}\right)$ in West Europe, retaining water from the Guadiana river basin, with a total storage capacity of $4150 \mathrm{hm}^{3}$, of which $3150 \mathrm{hm}^{3}$ are usable during regular operation (EDIA, 2013). The Alqueva dam and its irrigation network was a project ambitioned for many decades and planned so as to counteract the poor water availability in the region. It has been, since its implementation in the first decade of this century, the major driving force for the development and expansion of irrigated agriculture in the region, providing a steady source of water supply and lessening the vulnerability of local farming, traditionally limited by water availability and the typical variability that characterizes the Mediterranean climate.

The intensification of irrigation is susceptible to a build-up of soil degradation processes, causing a reduction in overall soil water storage capacity and an increase in surface runoff, resulting in a significant loss of soil fertility. Irrigation management practices will therefore have to be planned to balance shortterm economical returns with long-term sustainability, avoiding the effects contributing to the enhancement of the desertification processes.

Climate change, water availability and farming practices are indirectly interwoven with each other and many of the future challenges of a sustainable agricultural activity in the Guadiana river basin rely on both soil and water conservation practices to cope with the inevitable pressure of climate warming and rainfall reduction and irregularity.

Crop sensitivity to climate change is an important regional issue to be taken into account as adverse climate conditions can lead to considerable differences in overall basin-scale water consumption. Crop choices and irrigation management have a considerable effect in agriculture economic and environmental sustainability, and crop choice is frequently mentioned as one potential adaptation strategy to climate change. However, farmers often choose crops (woody perennial or herbaceous annual) based on a host of contextual factors such as crop revenue, water availability, soil conditions and government policies, disregarding climate change as a secondary concern.

Looking at this context, the main specific objectives of the present work can be described as to evaluate climate change for the Guadiana river basin and its impacts on the irrigation requirements of chosen crops within appropriate agricultural scenarios, as well as to evaluate the sustainability of such scenarios according to the water resources availability in the basin, holding policy decisions on water resources management integrating agricultural and other uses within the basin.

\section{Materials and methods}

\subsection{Description of the study area and crop distribution}

The study area is the Portuguese part of the Guadiana river basin, in southern Portugal. To allow an enhanced spatial resolution of climatic heterogeneities and, therefore, to provide a better assessment of the crop water use impacts, the Guadiana river basin was divided into six main units of analysis (UA) defined by the main subbasins of the tributaries of the Guadiana river. This spatial definition was adopted from previous works carried out under a pilot project for the development of a Portuguese Drought Forecasting and Management System (Serralheiro et al., 2010; Vivas et al., 2010; Vivas and Maia, 2010). Two additional spatial units ( 7 and 8) were added to those referred, representing areas located outside the Guadiana river basin - one (7) in the Sado river basin (Alentejo region) and the other (8) in the eastern part (Sotavento) of the southern Ribeiras do Algarve river basin (Algarve region) - but irrigated with water abstracted from it, as shown in Fig. 1. 


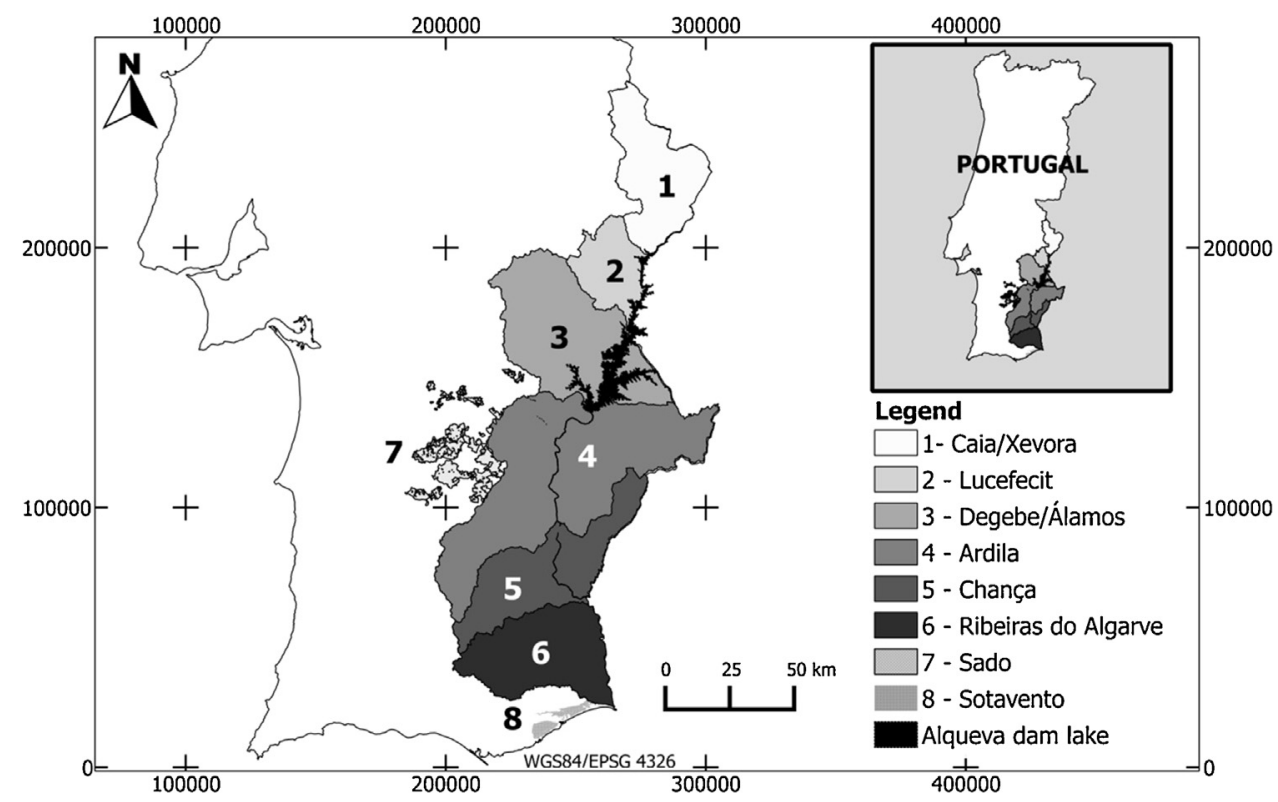

Fig. 1. Guadiana basin location and units of analysis (1-6) and additional ones ( 7 and 8). The Alqueva dam lake is seen adjacent to units of analysis $1-4$.

The present situation regarding irrigated crop distribution areas, related irrigation methods and water sources was defined using information collected from the RA2009 (2009 national agricultural census) (INE, 2011), and irrigated areas reported by the public organizations in charge of reservoir distribution networks management.

Irrigated agriculture in the Guadiana basin - from now on in this paper, that corresponds to all the UA supplied with water abstracted in the Guadiana basin - was thereby divided into two groups: annual and permanent crops. The permanent crops considered in this study include permanent natural pastures and woody crops: orchards (except citrus), citrus olive and grapevine. The crop selected for modelling orchards other than citrus was the peach tree. The annual crop group comprises maize/spring grain cereals, wheat (winter grain cereals), pulse, spring fodder (maize/sorghum), winter fodder (barley), sunflower, and horticulture crops. The crops were chosen in order to gather the most representative in the region and, in some cases, each crop item encloses several individual species with similar water requirements so as to represent the mid-to-upper limits of non-stressing soil water contents for each crop group and, therefore, to achieve maximum yield. The golf course fields have been included in the analysis of water requirements because, while not being a crop or livestock by definition, these irrigated areas have an important role in the local economy of the Algarve region and have displayed a significant expansion in the last decade, competing and sharing water resources with the traditional agricultural crops.

\subsection{Climate change scenarios (CCS)}

Five climate change scenarios (CCS 1-5), aimed to describe the general characteristics of a future climate, were produced using the Global climate model output from the World Climate Research Programme's (WCRP's) Coupled Model Inter-comparison Project phase 3 (CMIP3) multi-model dataset (Meehl et al., 2007), retrieved from www.engr.scu.edu/ emaurer/global_data/. This dataset was downscaled as described by Maurer et al. (2009) using the biascorrection/spatial downscaling method (Wood et al., 2004) to a 0.5 degrees grid, based on the 1950-1999 gridded observations of Adam and Lettenmaier (2003). The CMIP3 climate simulations datasets used in this study include the outputs of 16 IPCC Models under 3 future emissions scenarios (A2, B1, A1B), resulting in a total of 48 different climate projections containing monthly records of both precipitation and temperature at a $0.5^{\circ}$ spatial resolution for the period of 1950 to 2099. Each climate projection was extracted from the referred global climate archive (called "Globally Downscaled Climate Data") by clipping the data from the Guadiana basin's area coordinate's intervals $\left(40.5^{\circ} \mathrm{N}\right.$ to $37^{\circ} \mathrm{N}$ lat.; $1.5^{\circ} \mathrm{W}$ to $8.5^{\circ} \mathrm{W}$ long.). These bias-corrected and downscaled air temperature and rainfall projections, for the Guadiana river basin (Fig. 2), suggest that future climate will produce warmer and drier conditions.

The five CCS were defined to represent future possibilities and to bracket uncertainty. Four of the five CCS considered in this study (CCS 1, 2, 4 and 5) were defined in order to enclose different ranges/spread of projected air temperature and precipitation changes, with one middle scenario (CCS 3), representing the central tendency of projected changes of these climate variables (Bureau of Reclamation, 2009). Thus, it was necessary to establish a historical/reference period (1961-1990) as well as two different future periods (i) 2011-2040 (future 1) and 2041-2070 (future 2). The chosen climate change range of interest was defined as the intersection of the 25th to 75th percentile of changes in temperature and 25 th to 75 th percentile of changes in precipitation, while the central tendency correspond to the intersection of the median changes (50th percentile) in temperature and precipitation (Bureau of Reclamation, 2011). Table 1 summarizes, for each future period and CCS, the values obtained in terms of mean annual temperature and precipitation period-changes.

To inform each CCS, an ensemble of climate projections was chosen, accordingly with the ensemble-delta technique. The definition of CCS was conducted to support the development of climate inputs (the so-called climate-adjusted weather inputs) for the crop irrigation model (ISAREG) using the Ensemble Delta technique. This technique reflects changes in period monthly mean temperature and rainfall over the studied region, sampled from an ensemble of climate projections (Bureau of Reclamation, 2009). The ensembledelta technique comprises the calculation of 12-month-specific change factors for both precipitation and air temperature, for each cell (of $0.5^{\circ}$ resolution), and for each CCS (Ramos et al., 2014). Although, to run the crop model a higher resolution $\left(0.125^{\circ}\right.$ resolution) is important. Thus, the change factors were interpolated using Inverse Distance Weighting technique, and then applied (for a 


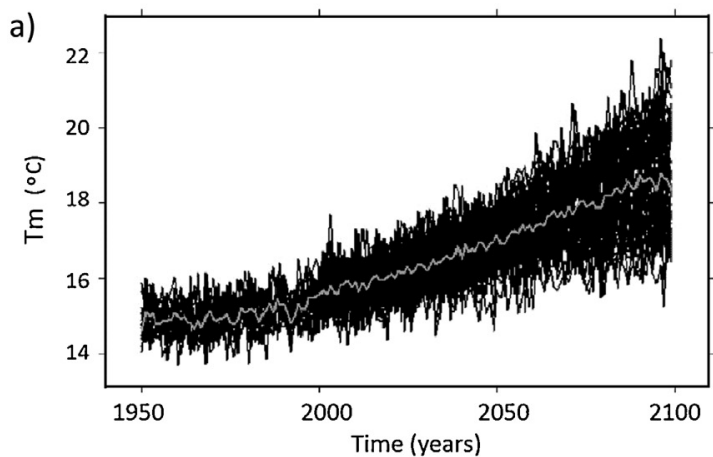

b)

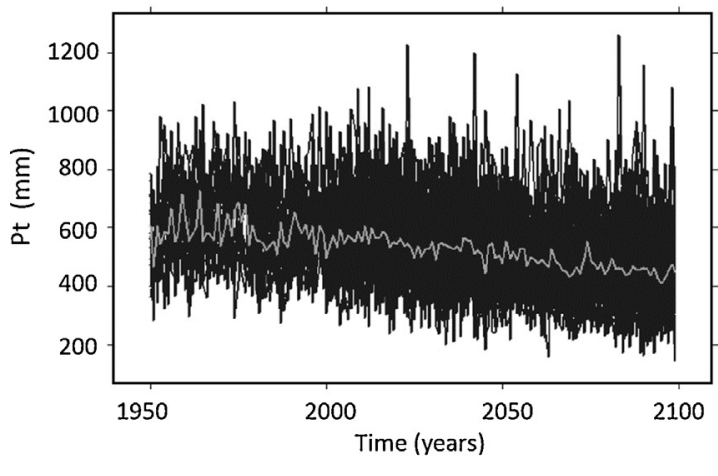

c)

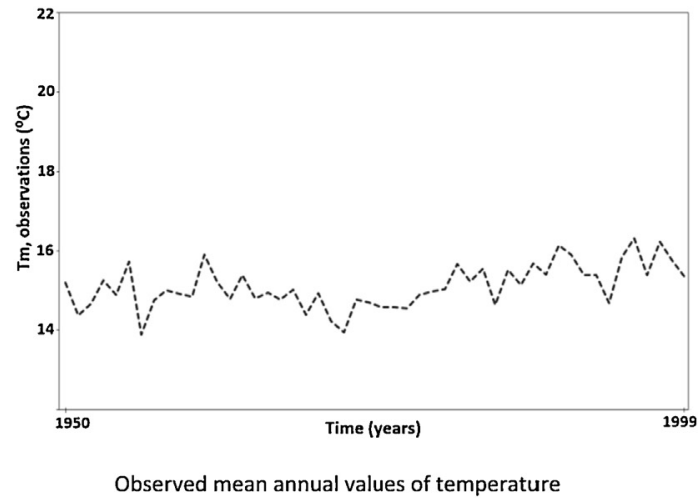

d)

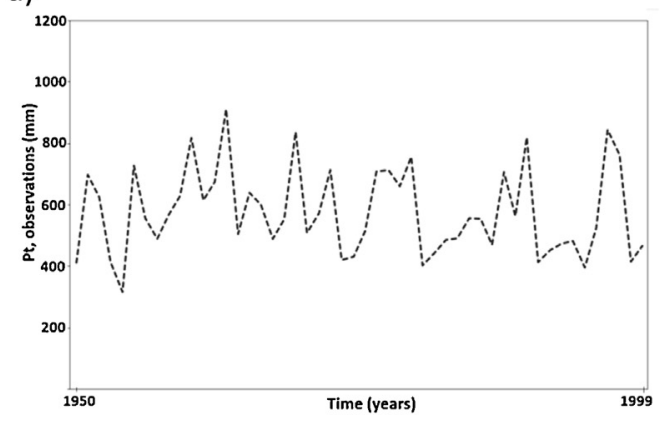

Observed mean annual values of precipitation

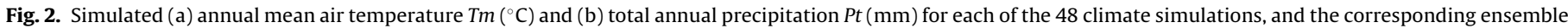

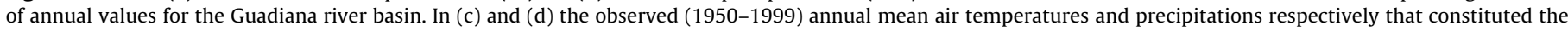
basic series for the simulations.

given month and climate variable) uniformly to the 30 observed climate series of the historical period, obtaining the climate adjusted weather (CAW) series. This implies that the generated CAW series replicate, for future periods, the historic inter-annual variation pattern contained in the underlying base reference data (Ramos et al., 2014).

Fig. 3 depicts the CAW air temperatures $\left({ }^{\circ} \mathrm{C}\right)$ series generated for the central tendency scenario (CCS 3 ) considering the spatial average of the UA considered in the Portuguese part of the Guadiana river basin. For both (a) future period 1 (2011-2040) and (b) future period 2 (2041-2070) the minimum, maximum and mean air temperatures (Tmin, Tmax, Tm) describe a rising tendency, with $\mathrm{Tm}$ reaching a maximum of $27.4^{\circ} \mathrm{C}$ for future period 1 and $28.4^{\circ} \mathrm{C}$ for future period 2 . Within both future periods 1 and 2 , the model predicts that Tmin will rise faster than Tmax, resulting in a decreasing thermal amplitude (Tmax - Tmin), as shown in Fig. $3 \mathrm{a}$ and $\mathrm{b}$ by a negative slope. Comparing the monthly averages of both 30-year future periods 1 and 2, the model predicts that minimum air temperatures will rise at a faster rate $\left(21.8-23.2^{\circ} \mathrm{C}\right)$ than the maximum temperatures $\left(33.4-34.4^{\circ} \mathrm{C}\right)$, resulting in an overall time-decreasing thermal amplitude. For the remaining CAW series, albeit built with different thresholds resulting in lower absolute values of the temperatures for CCS $(1,2)$ and higher temperatures for CCS $(4,5)$, the outputs display similar evolution tendencies, exhibiting a rising tendency of Tmin, Tmax and Tm and slightly decreasing thermal amplitude (Tmax - Tmin).

\subsection{Agricultural scenarios (AGS)}

To address the future outcomes of irrigated crop area occupation in the Guadiana river basin and associated irrigation-dependent areas, four basin-scale agricultural scenarios (AGS) were defined: Present, A, B and C, in order to address realistic evolution patterns of farmland given the current status and tendencies.

This section contains a description of three future scenarios of irrigated agriculture - called scenarios A, B, and C - referring

Table 1

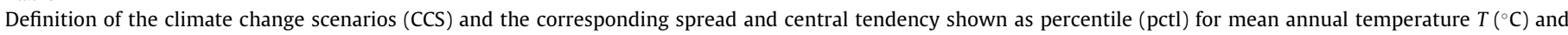
precipitation $P(\mathrm{~mm})$.

\begin{tabular}{|c|c|c|c|c|c|}
\hline Period & $\mathrm{CCS}$ & $T\left({ }^{\circ} \mathrm{C}\right)$ & & $P(\mathrm{~mm})$ & \\
\hline Future 1 (2011-2040) & $\begin{array}{l}1 \text { - warm and mildly dry } \\
2 \text { - warm and much dry } \\
3 \text { - hot and dry (central tendency) } \\
4 \text { - hotter and mildly dry } \\
5 \text { - hotter and much dry }\end{array}$ & $\begin{array}{l}0.99 \\
0.99 \\
1.23 \\
1.39 \\
1.39\end{array}$ & $\begin{array}{l}(25 \mathrm{pctl}) \\
(25 \mathrm{pctl}) \\
(50 \mathrm{pctl}) \\
(75 \mathrm{pctl}) \\
(75 \mathrm{pctl})\end{array}$ & $\begin{array}{r}-4.89 \\
-10.70 \\
-8.76 \\
-4.89 \\
-10.70\end{array}$ & $\begin{array}{l}(75 \mathrm{pctl}) \\
(25 \mathrm{pctl}) \\
(50 \mathrm{pctl}) \\
(75 \mathrm{pctl}) \\
(25 \mathrm{pctl})\end{array}$ \\
\hline Future 2 (2041-2070) & $\begin{array}{l}1 \text { - warm and mildly dry } \\
2 \text { - warm and much dry } \\
3 \text { - hot and dry (central tendency) } \\
4 \text { - hotter and mildly dry } \\
5 \text { - hotter and much dry }\end{array}$ & $\begin{array}{l}1.73 \\
1.73 \\
2.31 \\
2.61 \\
2.61\end{array}$ & $\begin{array}{l}(25 \mathrm{pctl}) \\
(25 \mathrm{pctl}) \\
(50 \mathrm{pctl}) \\
(75 \mathrm{pctl}) \\
(75 \mathrm{pctl})\end{array}$ & $\begin{array}{r}-9.80 \\
-21.79 \\
-15.20 \\
-9.80 \\
-21.79\end{array}$ & $\begin{array}{l}(75 \mathrm{pctl}) \\
(25 \mathrm{pctl}) \\
(50 \mathrm{pctl}) \\
(75 \mathrm{pctl}) \\
(25 \mathrm{pctl})\end{array}$ \\
\hline
\end{tabular}


a) Future 1

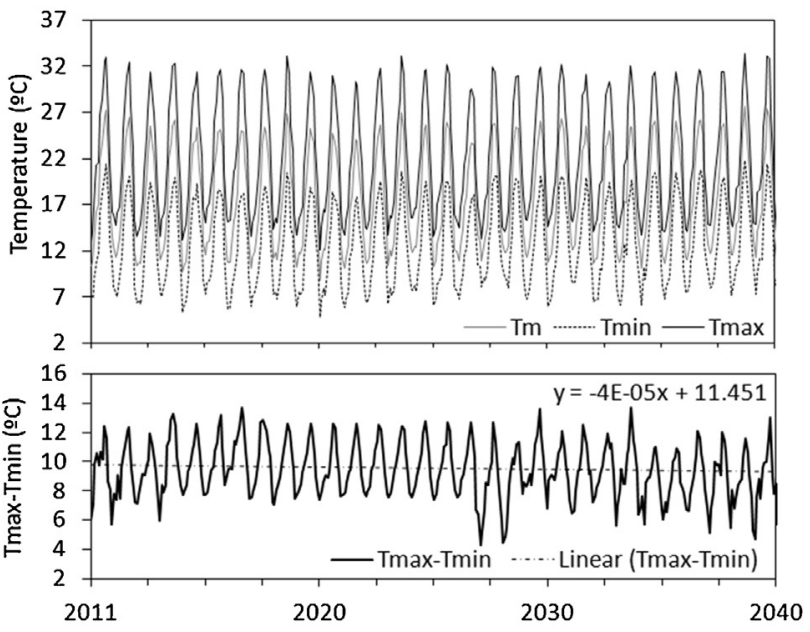

b) Future 2

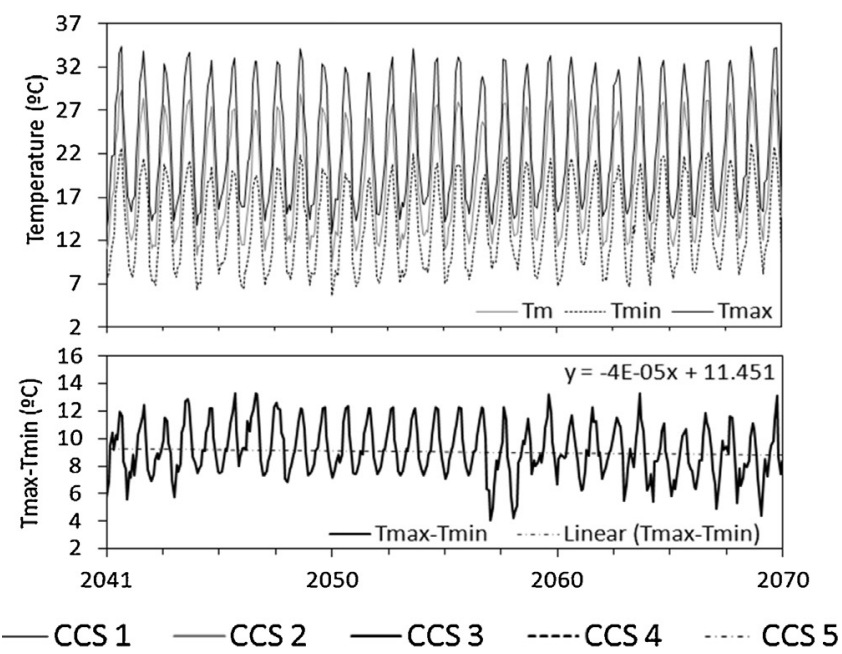

Fig. 3. Monthly average CAW air temperatures series $\left({ }^{\circ} \mathrm{C}\right.$ ) for (a) future period 1 (2011-2040); and (b) future period 2 (2041-2070), representing maximum (Tmax), minimum (Tmin), mean (Tm) and thermal amplitude (Tmax - Tmin) generated for CCS 3.

to the areas that may be occupied in the units of analysis in the Guadiana river basin by the main irrigated crops. It should be noted that, although just the irrigated crops are considered herein, each irrigation scenario corresponds to an agricultural scenario including the areas of rainfed crops, because irrigation and rainfed cropping are always inter-dependent and complimentary systems. Therefore, the agricultural scenarios also aim to address the possible area-management exchange outcomes between irrigated and rain-fed crops as a response to climate change and future water availability contexts. The total cultivated area remaining constant, each increase in irrigated area is compensated by an equal decrease in rainfed area. On the other hand, scenarios A, B, and C represent different developments with reference to the Present situation, which is described first.

Present situation was defined on the basis of the 2009 agricultural inquiry (INE, 2011), which contains data on total irrigated areas and its distribution by the main irrigated crops. Water sources for agriculture in the Guadiana basin include mainly public water storage structures (medium to large public dams such as Alqueva), but also water extraction from small private dams and groundwater sources (private water sources). As the irrigated areas in the public sector (irrigation districts) are well known from official reports, the "private irrigated areas" could be deducted. Moreover, as total irrigated area is modifying fast in the Guadiana basin with the implementation of the Alqueva project, it was updated to 2011 by adding the new irrigation blocks meanwhile converted from rainfed to irrigated agriculture. On the other hand, the new irrigated areas were attributed the proportions of the 2009 inquiry for distribution of the irrigated areas by the crops. The Present scenario is numerically characterized in Table 2.

Scenario A was defined as the situation of irrigated agriculture that may be expected for 2020, assuming that the Alqueva project will be complete and completely used at that time. In the region of Alentejo, which encloses most of the Guadiana Basin area, the total area of irrigated land increased between 1999 and 2009 (INE, 2011) by around $17 \%$, or 20,086 ha. Much of this increase is attributed to the new irrigation network-equipped areas made available by the Alqueva dam (EDIA, 2013), but it is clear that there was also a significant investment in this type of agricultural intensification relying on private sources of water. Therefore, for each of the UA in the Guadiana basin, an identical growth of $17 \%$ in the irrigated areas was considered, for both public and private water sources.

Private irrigation systems were considered to increase maintaining the current proportions to the public irrigated sector, reflecting the observed regional interest on irrigated agriculture. In what concerns the distribution of the irrigated crops in the irrigation area, present proportions were considered with some modifications that look realistic on the basis of current data and tendencies. Therefore, the areas with olive groves and vineyards were considered to increase at the rhythms observed for the former decade between the agricultural inquiries of 1999 and 2009 (INE, 2011). The increase in irrigated areas was done with equivalent reduction in rainfed areas, mainly winter cereals and fodder crops. In this scenario it is assumed that irrigation water will maintain a relatively low price as the present status, with water subsidized by the government as part of irrigation expansion incentive policy. In Table 3 these criteria were applied to the numerical characterization of agricultural scenario A.

Scenario B was thought to exist by the years 2030 and 2040, if the current interest in irrigated agriculture is maintained. Therefore, this scenario is the most optimistic assuming high availability and thus low price of water, which consequently translates to the highest expansion of irrigation areas. For this case, a $45 \%$ area increase was considered upon scenario A, corresponding to an increase of 50,000 ha in the area served by the Alqueva system. This hypothesis is being considered and planned by the Alqueva authorities, irrigators associations and other regional stakeholders. If it reveals sustainable, the increase in irrigated area will be compensated by an equivalent decrease in rainfed area with winter cereals and fodder crops, the irrigated area being distributed by crop groups maintaining the proportions in scenario A. For this scenario $B$ to be sustainable, it requires enormous efforts from the agricultural sector to improve technology, mainly for soil, water, and energy conservation. Scenario B is numerically characterized in Table 4.

Scenario $C$ is defined as a conservative alternative to the intensive water use scenario $\mathrm{B}$, and will be characterized by a high awareness of farmers to sustainable agricultural practices due to high water prices in a scarcity context. Scenario $C$ was thought as to exist by the years 2030 and 2040, as alternative opposing to scenario $B$. For scenario $C$ the costs of water, energy, other production factors, soil and water conservation and other technological applications were considered more relevant, reducing the interest in irrigation, and therefore the irrigated areas. In this context, the irrigated areas of scenario A were considered for scenario C, along with some redistribution of irrigated areas by the crop groups, looking for the reduction of water requirements, of energy and other costs 
Table 2

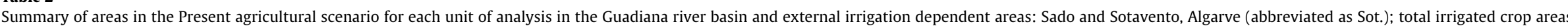
(public and private water sources) $-T$ (ha), and areas irrigated with private sources of water (small dams and groundwater) $-P($ ha).

\begin{tabular}{|c|c|c|c|c|c|c|c|c|c|c|c|c|c|c|c|c|c|c|}
\hline \multirow[t]{3}{*}{ Crops } & \multicolumn{18}{|c|}{ Agricultural scenario present - units of analysis } \\
\hline & \multicolumn{2}{|l|}{1} & \multicolumn{2}{|l|}{2} & \multicolumn{2}{|l|}{3} & \multicolumn{2}{|l|}{4} & \multicolumn{2}{|l|}{5} & \multicolumn{2}{|l|}{6} & \multicolumn{2}{|l|}{ Sado } & \multicolumn{2}{|l|}{ Sot } & \multicolumn{2}{|l|}{ Total } \\
\hline & $T$ & $P$ & $T$ & $P$ & $T$ & $P$ & $T$ & $P$ & $T$ & $P$ & $T$ & $P$ & $T$ & $P$ & $T$ & $P$ & $T$ & $P$ \\
\hline Maize/spring grain cereals & 1200 & 51 & 650 & 203 & 1767 & 239 & 183 & 183 & 11 & 11 & 15 & 15 & 939 & 0 & 0 & 0 & 4765 & 702 \\
\hline Wheat/winter grain cereals & 2029 & 518 & 417 & 328 & 1991 & 1094 & 1459 & 1459 & 121 & 121 & 6 & 6 & 751 & 0 & 0 & 0 & 6774 & 3526 \\
\hline Grain legumes & 206 & 62 & 145 & 5 & 17 & 12 & 38 & 38 & 4 & 4 & 6 & 6 & 87 & 0 & 0 & 0 & 503 & 127 \\
\hline Spring fodder & 247 & 228 & 92 & 29 & 586 & 354 & 145 & 145 & 7 & 7 & 12 & 12 & 94 & 0 & 0 & 0 & 1183 & 775 \\
\hline Winter fodder & 393 & 238 & 160 & 143 & 1329 & 626 & 589 & 589 & 149 & 149 & 5 & 5 & 263 & 0 & 0 & 0 & 2888 & 1750 \\
\hline Sunflower/oleaginous & 296 & 103 & 12 & 11 & 367 & 79 & 992 & 992 & 97 & 97 & 0 & 0 & 145 & 0 & 0 & 0 & 1909 & 1282 \\
\hline Horticulture & 1709 & 489 & 302 & 255 & 787 & 344 & 514 & 514 & 63 & 63 & 102 & 71 & 523 & 0 & 156 & 0 & 4156 & 1736 \\
\hline Pastures & 277 & 107 & 57 & 15 & 627 & 50 & 526 & 526 & 49 & 49 & 205 & 205 & 237 & 0 & 0 & 0 & 1978 & 952 \\
\hline Fruit orchards (except citrus) & 630 & 223 & 285 & 266 & 138 & 96 & 147 & 147 & 191 & 191 & 239 & 220 & 146 & 0 & 138 & 0 & 1914 & 1143 \\
\hline Citrus & 96 & 22 & 34 & 32 & 110 & 76 & 222 & 222 & 43 & 43 & 1366 & 1274 & 61 & 0 & 1431 & 0 & 3363 & 1669 \\
\hline Olive groves & 3804 & 1511 & 612 & 441 & 5480 & 2253 & 18407 & 18407 & 2411 & 2411 & 47 & 47 & 1710 & 0 & 0 & 0 & 32471 & 25070 \\
\hline Grapevine & 405 & 340 & 1135 & 989 & 5623 & 3549 & 2463 & 2463 & 137 & 137 & 63 & 54 & 689 & 0 & 66 & 0 & 10581 & 7532 \\
\hline Golf course fields & 0 & 0 & 0 & 0 & 0 & 0 & 0 & 0 & 0 & 0 & 34 & 0 & 0 & 0 & 126 & 0 & 160 & 0 \\
\hline Total & 11292 & 3892 & 3901 & 2715 & 18822 & 8772 & 25684 & 25684 & 3283 & 3283 & 2100 & 1915 & 5645 & 0 & 1917 & 0 & 72644 & 46261 \\
\hline
\end{tabular}

Table 3

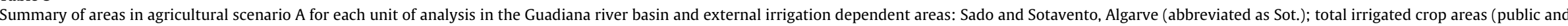
private water sources) $-T$ (ha), and areas irrigated with private sources of water (small dams and groundwater) $-P$ (ha).

\begin{tabular}{|c|c|c|c|c|c|c|c|c|c|c|c|c|c|c|c|c|c|c|}
\hline \multirow[t]{3}{*}{ Crops } & \multicolumn{18}{|c|}{ Agricultural scenario A - units of analysis } \\
\hline & \multicolumn{2}{|l|}{1} & \multicolumn{2}{|l|}{2} & \multicolumn{2}{|l|}{3} & \multicolumn{2}{|l|}{4} & \multicolumn{2}{|l|}{5} & \multicolumn{2}{|l|}{6} & \multicolumn{2}{|l|}{ Sado } & \multicolumn{2}{|l|}{ Sot } & \multicolumn{2}{|l|}{ Total } \\
\hline & $T$ & $P$ & $T$ & $P$ & $T$ & $P$ & $T$ & $P$ & $T$ & $P$ & $T$ & $P$ & $T$ & $P$ & $T$ & $P$ & $T$ & $P$ \\
\hline Maize/spring grain cereals & 1209 & 60 & 685 & 238 & 1808 & 280 & 11230 & 214 & 14 & 14 & 18 & 18 & 7411 & 0 & 0 & 0 & 22375 & 824 \\
\hline Wheat/winter grain cereals & 2117 & 606 & 473 & 383 & 2177 & 1280 & 10514 & 1707 & 141 & 141 & 7 & 7 & 5925 & 0 & 0 & 0 & 21354 & 4124 \\
\hline Grain legumes & 217 & 73 & 146 & 6 & 19 & 14 & 1062 & 44 & 5 & 5 & 7 & 7 & 684 & 0 & 0 & 0 & 2140 & 149 \\
\hline Spring fodder & 286 & 267 & 97 & 33 & 646 & 414 & 1277 & 169 & 8 & 8 & 14 & 14 & 745 & 0 & 0 & 0 & 3073 & 905 \\
\hline Winter fodder & 434 & 279 & 184 & 168 & 1435 & 733 & 3772 & 689 & 174 & 174 & 6 & 6 & 2074 & 0 & 0 & 0 & 8079 & 2049 \\
\hline Sunflower/oleaginous & 314 & 121 & 14 & 12 & 380 & 93 & 2858 & 1160 & 113 & 113 & 0 & 0 & 1143 & 0 & 0 & 0 & 4822 & 1499 \\
\hline Horticulture & 1792 & 572 & 345 & 298 & 845 & 402 & 6744 & 602 & 73 & 73 & 114 & 83 & 4132 & 0 & 400 & 0 & 14445 & 2030 \\
\hline Pastures & 295 & 125 & 60 & 18 & 635 & 58 & 3397 & 616 & 57 & 57 & 240 & 240 & 1872 & 0 & 0 & 0 & 6556 & 1114 \\
\hline Fruit orchards (except citrus) & 668 & 261 & 330 & 311 & 154 & 113 & 1890 & 172 & 224 & 224 & 276 & 257 & 1156 & 0 & 354 & 0 & 5052 & 1338 \\
\hline Citrus & 100 & 25 & 40 & 38 & 123 & 89 & 972 & 260 & 51 & 51 & 1583 & 1491 & 480 & 0 & 3669 & 0 & 7018 & 1954 \\
\hline Olive groves & 4091 & 1798 & 696 & 525 & 5908 & 2681 & 41972 & 21904 & 2870 & 2870 & 56 & 56 & 13501 & 0 & 0 & 0 & 69094 & 29834 \\
\hline Grapevine & 538 & 472 & 1521 & 1374 & 7007 & 4934 & 11513 & 3423 & 191 & 191 & 85 & 76 & 5442 & 0 & 169 & 0 & 26466 & 10470 \\
\hline Golf course fields & 0 & 0 & 0 & 0 & 0 & 0 & 0 & 0 & 0 & 0 & 34 & 0 & 0 & 0 & 323 & 0 & 357 & 0 \\
\hline Total & 12059 & 4659 & 4589 & 3403 & 21139 & 11090 & 97202 & 30961 & 3921 & 3921 & 2439 & 2254 & 44564 & 0 & 4915 & 0 & 190828 & 56288 \\
\hline
\end{tabular}




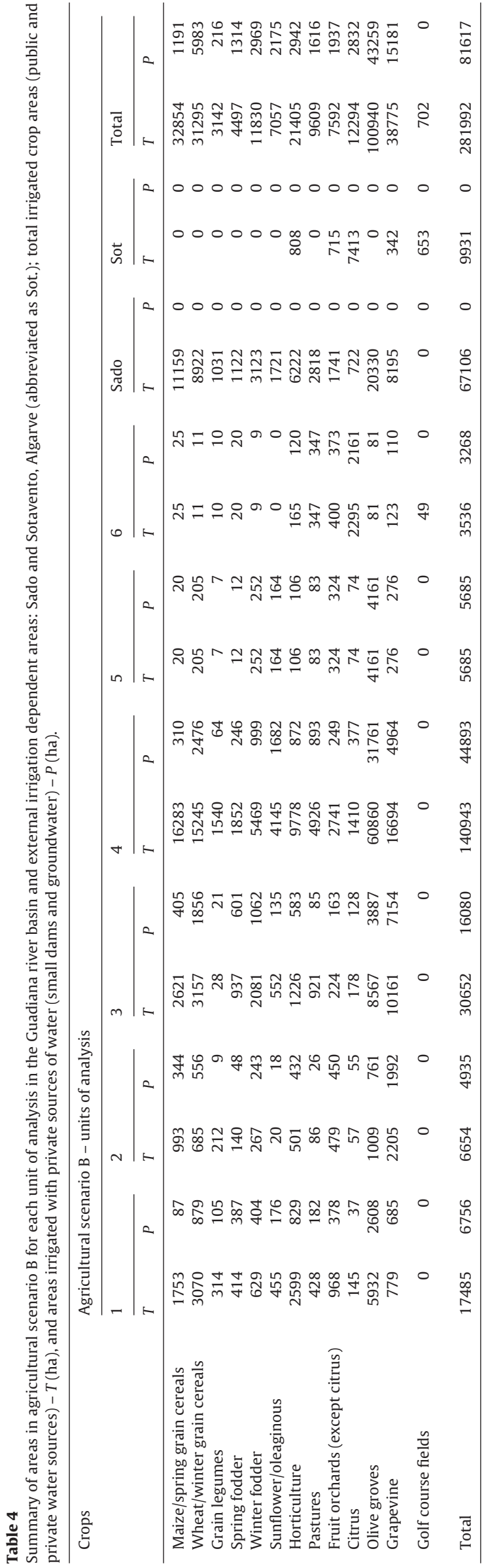

of irrigation production factors. In this context, the following steps were taken for building scenario $\mathrm{C}$ upon scenario A:

The area with maize in scenario A was reduced in 65\% that was converted to irrigated winter cereals and fodder crops;

The areas with olive groves and vineyards in Scenario A will maintain in scenario $\mathrm{C}$;

Some areas with irrigated herbaceous crops were redistributed to irrigated woody perennial crops, mainly orchards but also traditional rainfed forest species on limited quality soils;

The areas with herbaceous irrigated crops were finally arranged for each UA in order to be $2 / 3$ with winter crops (less water demanding) and $1 / 3$ with spring and summer crops.

Table 5 contains the numerical characterization of scenario $\mathrm{C}$.

The Sado and Sotavento are irrigation areas outside the Guadiana basin, but still dependent on the Alqueva dam irrigation system and so these areas were accounted for as part of the public-sourced water consumption share of the studied basin.

Irrigation efficiency was determined as specific to each irrigation method, improving in future scenarios according to the technological constraints, specially the costs of the irrigation water. On the other hand, the RA 2009 (INE, 2011) contains information on the irrigation methods used for each crop group. Therefore, assuming that irrigation methods will likely remain proportional in the future, irrigation efficiency could be calculated for each scenario. Most crops are served by one or two irrigation methods, woody crops (olive and grapevine) rely heavily on drip irrigation while grain cereals are mostly irrigated with sprinklers. There are still traces of gravity irrigation in the Guadiana river basin, but supported by modern management (piped gravity irrigation), allowing relatively high irrigation efficiencies, comparable to sprinkler irrigation. Considering the existence of little future potential for improvement, the average irrigation efficiencies were assumed as 0.85 for drip irrigation, and 0.75 for both sprinkler and gravity irrigation.

The proportion between water consumption from private water sources (small private dams and groundwater extraction) and public water sources (large dams) has been established (as of 2009) from combined information from the agricultural census 2009 (INE, 2011) and public dam management reports. Groundwater is currently not a heavily explored water source for agricultural purposes in the region, being usually deprecated in favour of surface water sources, although it has considerable importance in smaller farms not served by publicly managed irrigation networks. In this study it was assumed, for the future scenarios, that water used in irrigation from private water sources will maintain its current distribution ratio between surface and groundwater origins for each crop and UA.

\subsection{Crop net irrigation requirements}

Crop net irrigation requirements were determined by way of the ISAREG water balance model, developed at the Instituto Superior de Agronomia (ISA) by Teixeira and Pereira (1992). The model estimates crop net irrigation needs implementing a soil water balance algorithm, based on the FAO methodology (Doorenbos and Pruitt, 1977; Doorenbos and Kassam, 1979), later enhanced by Allen et al. (1998) in which the soil is considered a reservoir, giving in or receiving water at any period of time, depending on the balance between the inputs (precipitation, irrigation) and outputs (crop evapotranspiration, drainage, deep percolation) (Teixeira and Pereira, 1992). In this study the inputs to the model were the effective precipitation (Pef), reference evapotranspiration (ETo), soil water data (depth of soil horizon, upper and lower limits of available water, i.e. field capacity and wilting point), and the characteristics of crop growth 


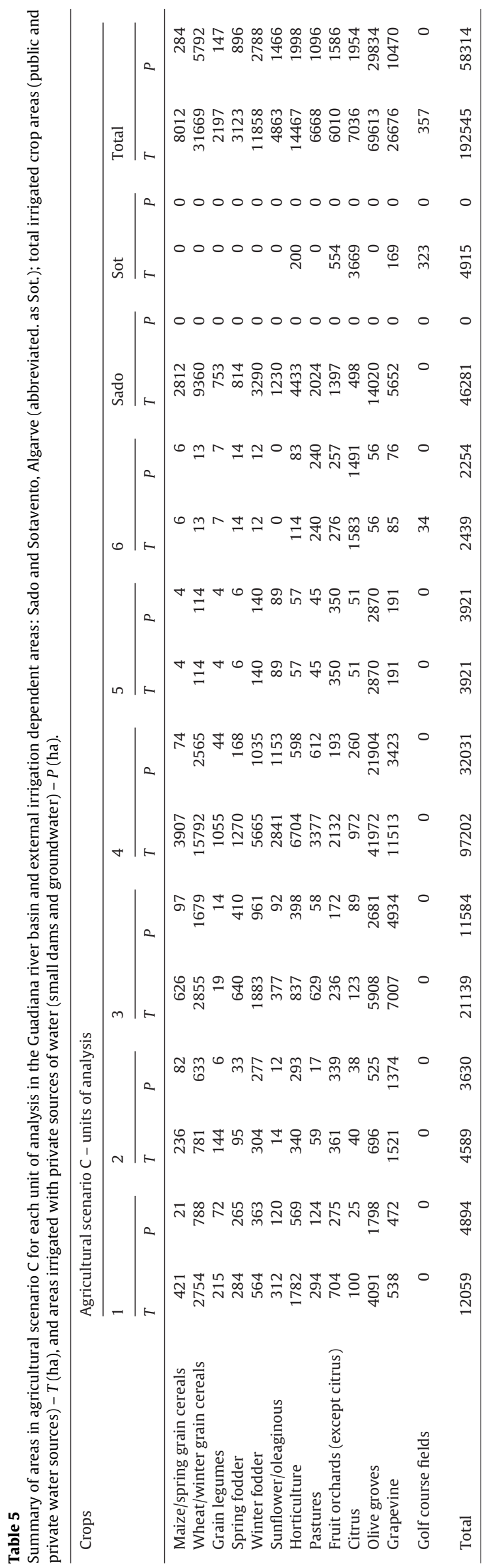

throughout the crop cycle (root depth, lower limit of available soil water for maximum yield, duration of the crop growth stages, crop coefficients). In the present work, a simplified model of soil profile was used for annual herbaceous crops, with a unique horizon of $60 \mathrm{~cm}$ depth and $100 \mathrm{~mm}$ available water capacity. The model was set to simulate irrigation to achieve maximum yield, where irrigation is applied to reach soil water field capacity whenever soil moisture reaches the limit of the readily available soil water in the root zone.

Effective precipitation, Pef is the fraction of the total rainfall contributing to both soil water storage in the crop root zone and deep drainage. The methodologies available to determine Pef from total precipitation data $(P t)$ account for the loss of soil water intake due to the effects on runoff from local topography, soil texture and leaf interception by vegetation. In this study, the effective precipitation (Pef) used as input in the ISAREG model was determined, for each unit of analysis, using the method defined in (Eq. (1)), originating from the USDA Soil Conservation Service (USDA-SCS) (Clarke, 1998), where Pt is the total precipitation ( $\mathrm{mm}$ ), estimated as the area-weighted average precipitation in each unit of analysis within the Guadiana basin.

$P e f= \begin{cases}\frac{P t(125-0.2 P t)}{125} & ;(P t<250 \mathrm{~mm}) \\ 125+0.1 P t & ;(P t \geq 250 \mathrm{~mm})\end{cases}$

Reference evapotranspiration (ETo) estimates are widely used to define crop water requirements. The Modified Penman-Monteith (FAO-56 PM), presented by FAO Irrigation \& Drainage Paper No.56 (Allen et al., 1998) is currently the standard method to estimate $E T o$, but is relatively high data demanding, making it suitable for computing evapotranspiration with data from automatic weather stations, but impracticable to use with global climate datasets which often provide a limited set of climate variables. Santos and Maia (2005) have studied datasets from the COTR - SAGRA automatic weather station network located in the Alentejo region, partially enclosing the Guadiana river basin, and found that for nine different weather stations, the linear regression results of the Hargreaves-Samani (HS) equation (Hargreaves and Samani, 1985) versus the standard FAO-56 PM in the Guadiana river basin returned an average determination coefficient of 0.9 . Other studies also found that the HS equation, despite its simplicity, returns results comparable to the more accurate FAO-56 PM equation (Droogers and Allen, 2002; Shahidian et al., 2012). The reference evapotranspiration (ETo) was estimated for the 8 units of analysis and climate scenarios (CCS) using the HS equation for semi-arid regions (Eq. (2)) where $R a$ is the average extra-terrestrial radiation $\left(\mathrm{mm} \mathrm{day}^{-1}\right)$ and Tmax, Tmin and Tmed, are respectively the maximum, minimum and average air temperatures $\left({ }^{\circ} \mathrm{C}\right)$.

$E T o=0.0023 R a(T \max -T \min )^{0.5}($ Tmed +17.8$)$

Table 6 lists the crop coefficients and ground cover reduction coefficients used in the ISAREG model to estimate monthly net irrigation requirements for main growth stages of each representative crop under non-limiting water supply conditions, given the effective rainfall (Pef) and ETo estimated for each of the climate scenarios (CCS1-5) and future periods considered in this study. The average crop coefficients $(K c)$ used were based on those proposed by FAO (Allen et al., 1998) for the Mediterranean conditions, although introducing adjustments to reflect the local crop development stages namely planting and harvest timeframes, management conditions, and considering, where applicable, the appropriate $\mathrm{Kc}$ for the established crop densities.

The golf fields, while not being directly related to agriculture, were introduced in this study because of their increasing importance to the economy, especially in the Sotavento region of the 
Table 6

Crop coefficients, ground cover, and growth stages duration considered in the ISAREG model.

\begin{tabular}{|c|c|c|c|c|c|c|c|c|c|}
\hline \multirow[t]{2}{*}{ Crop } & \multirow[t]{2}{*}{ Ground cover (\%) } & \multicolumn{3}{|c|}{ Kc/crop stage } & \multirow[t]{2}{*}{ Start date } & \multicolumn{4}{|c|}{ Crop stage length } \\
\hline & & Initial & Mid & Final & & Initial & Mid & Final & Late \\
\hline Maize/spring grain cereals & - & 0.30 & 1.20 & 0.35 & 1-May & 30 & 50 & 60 & 40 \\
\hline Wheat/winter grain cereals & - & 0.30 & 1.15 & 0.25 & 15-November & 30 & 140 & 40 & 30 \\
\hline Grain legumes & - & 0.50 & 1.15 & 0.30 & 01-December & 40 & 35 & 35 & 25 \\
\hline Winter fodder & - & 0.30 & 1.15 & 0.25 & 15-November & 30 & 140 & 40 & 30 \\
\hline Spring fodder & - & 0.30 & 1.20 & 0.35 & 1-May & 25 & 37 & 30 & 34 \\
\hline Horticulture & - & 0.60 & 1.15 & 0.90 & 15-April & 30 & 40 & 45 & 30 \\
\hline Sunflower & - & 0.35 & 1.15 & 0.35 & 15-March & 25 & 35 & 45 & 25 \\
\hline Pastures & - & 0.30 & 0.75 & 0.75 & 01-October & 140 & 60 & 120 & 24 \\
\hline Fruit Orchards (peaches) & 70 & 0.55 & 0.90 & 0.65 & 1-March & 92 & 30 & 61 & 30 \\
\hline Citrus & 70 & 0.70 & 0.65 & 0.70 & 1-March & 150 & 64 & 50 & 38 \\
\hline Olive groves & 59 & 0.65 & 0.50 & 0.50 & 1-March & 30 & 90 & 60 & 90 \\
\hline Grapevine & 50 & 0.30 & 0.70 & 0.00 & 1-March & 30 & 120 & 32 & 56 \\
\hline Golf fields & - & 0.30 & 0.75 & 0.75 & 01-October & 140 & 60 & 120 & 24 \\
\hline
\end{tabular}

Algarve, in the Guadiana river basin. With the expansion of the Alqueva irrigation network providing a steady source of water, golf fields are seen as an economic opportunity for local development and can become a competitor with agriculture for water. From the water use standpoint, golf courses are diverse landscapes, usually with vast permanent diverse species grass areas (with diverse water requirements) and sparse shrubs and trees to provide sun coverage and habitat for wildlife. For the purposes of this study the irrigation requirements of golf fields were considered analogous to well irrigated permanent pastures, with an "initial" relatively long (140 days) stage coincident with low strengthening fall and winter periods.

\section{Results and discussion}

\subsection{Climate trends and generated climate scenarios}

Each CCS was defined through the combination of rainfall and air temperature changes relative to the historical period (1961-1990) as shown in Table 1 . Annual rainfall shows a decreasing trend for both future periods. Future period 1 annual rainfall projected averages are between $515 \mathrm{~mm}$ (CCS 2 and 5) and $552 \mathrm{~mm}$ (CCS 4) and, under the more adverse conditions of future period 2 , the rainfall averages are lower, falling within 438 for CCS 2 to $517 \mathrm{~mm}$ (CCS 4).

The average daily ETo was determined using the temperaturebased HS equation (2), resulting from each CCS, returning a higher atmospheric demand in future 2 (2041-2070), with an average ETo ranging from 3.29 to $3.40 \mathrm{~mm} \mathrm{day}^{-1}$, while future 1 (2011-2040) outputs an average ETo range between 3.23 and $3.27 \mathrm{~mm} \mathrm{day}^{-1}$. Although the overall mean temperature Tmed, and the maximum Tmax and minimum Tmin temperatures increase over time in both future periods (Figs. 2a and 3), the ETo determined by the HS method did not return a significant ETo temporal trend. This may be due to the fact that, in the simulated CCS scenarios, Tmin grows faster than Tmax, thereby decreasing (although slightly), over the years, both the thermal difference used in the Hargreaves-Samani equation (Eq. (2)) and the ETo values calculated with this equation, reducing its reliability in simulating ETo trends for distant future periods, whilst using the CCS as primary data sources.

\subsection{Net irrigation requirements}

Crop choice is one of the possible adaptation strategies to cope with climate changes and water availability. Depending on whether rainfall increase or decrease, farmers will tend to shift towards either drought tolerant or water demanding crops respectively, in order to maximize economic return. The different combinations of rainfall and air temperature variations considered in each CCS affect the irrigation requirements of each crop differently. Therefore, despite the previously mentioned erratic behaviour of the ETo trends when calculated with the Hargreaves-Samani equation (Eq. (2)), it is important to address the effects of each CCS in the average net irrigation requirements. Table 7 lists the average annual net irrigation requirements estimated by the ISAREG model, given the 30-year historic reference period (1961-1990) climate and considering the representative crops selected.

Table 7 also summarizes, for each crop type, the net irrigation requirements determined by the ISAREG model using as inputs the climate data (ETo and Pef) generated from each CCS, aggregating the average results from the eight spatial units of analysis irrigated areas supplied by water abstractions in the Guadiana river basin.

Maize, horticulture, and fruit trees, as well as permanent irrigated crops such as pasture, are some of the most water demanding crops, exhibiting higher irrigation demands. The crops' response to different climate change scenarios is particularly important to the overall irrigation water demand. The impacts of each CCS on crop irrigation requirements are different, as crops respond differently to each threshold of rainfall and temperature variations. The maximum net irrigation requirements occur within CCS-3-CCS-5, which is coherent with their definitions (Table 1), corresponding to climate conditions of higher air temperatures and lower annual rainfall. However, the underlying monthly distribution of climate variables also has an important effect on how each crop will respond to a given CCS, as some crops are more sensitive to changes occurring in certain months, in accordance with its specific crop cycle. The results show that high rainfall decrease will have a more noticeable effect on the winter crops' irrigation needs, while a temperature increase will tend to increase water demand more noticeably on permanent crops with crop cycles occurring in spring and summer months. The range of irrigation demand variation between CCS for each crop and its corresponding standard deviation can be used as an indicator of the crop response to different climate change thresholds.

Grain legumes are short-cycle winter crops with typically low irrigation requirements, which consequently show very small variation response in irrigation demand for different CCS, exhibiting the lowest range of variation and standard deviation within the selected crops for both future periods.

The crops which are the most adapted to Mediterranean conditions such as olive and grapevine show a similarly small range of annual variation between CCS: 73 and $79 \mathrm{~m}^{3} \mathrm{ha}^{-1}$ for future period 1 and 198 and $186 \mathrm{~m}^{3} \mathrm{ha}^{-1}$ for future period 2 . The modest standard deviations of olive and grapevine relative to other crops also confirms that the irrigation demands of these crops have a smaller 
Table 7

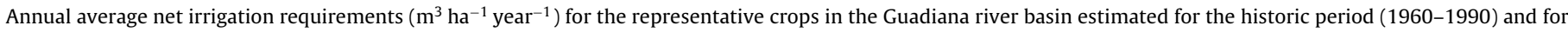
each CCS and descriptive climate-induced variations (variation range; standard deviation, SD; and coefficient of variation, CV) between CCS outputs.

\begin{tabular}{|c|c|c|c|c|c|c|c|c|c|}
\hline Crop & Historic period & CCS -1 & $\mathrm{CCS}-2$ & $\mathrm{CCS}-3$ & CCS -4 & CCS -5 & Range & SD & $\mathrm{CV}$ \\
\hline \multicolumn{10}{|l|}{ Future 1 (2011-2040) } \\
\hline Maize/Spring grain cereals & 5663 & 5919 & 5970 & 6056 & 6081 & 6071 & 162 & 71.4 & 1.2 \\
\hline Wheat/Winter grain cereals & 1654 & 1796 & 1930 & 1932 & 1904 & 1891 & 136 & 55.4 & 2.9 \\
\hline Grain legumes & 244 & 275 & 303 & 307 & 266 & 275 & 41 & 18.5 & 6.5 \\
\hline Spring fodder & 3797 & 4001 & 4025 & 4039 & 4033 & 4066 & 65 & 23.5 & 0.6 \\
\hline Winter fodder & 1654 & 1796 & 1930 & 1932 & 1904 & 1891 & 136 & 55.4 & 2.9 \\
\hline Sunflower/oleaginous & 3349 & 3577 & 3650 & 3671 & 3663 & 3676 & 99 & 40.6 & 1.1 \\
\hline Horticulture & 5647 & 5935 & 5980 & 6017 & 6049 & 6043 & 114 & 47.6 & 0.8 \\
\hline Pastures & 4978 & 5301 & 5418 & 5454 & 5460 & 5451 & 159 & 66.8 & 1.2 \\
\hline Fruit orchards (except citrus) & 5128 & 5402 & 5528 & 5576 & 5589 & 5583 & 186 & 78.3 & 1.4 \\
\hline Citrus & 4225 & 4415 & 4556 & 4625 & 4616 & 4628 & 213 & 90.4 & 2.0 \\
\hline Olive groves & 1441 & 1587 & 1628 & 1644 & 1658 & 1660 & 73 & 29.9 & 1.8 \\
\hline Grapevine & 2916 & 3122 & 3156 & 3186 & 3193 & 3201 & 79 & 32.5 & 1.0 \\
\hline Other: golf courses & 4978 & 5301 & 5418 & 5454 & 5460 & 5451 & 159 & 66.8 & 1.2 \\
\hline \multicolumn{10}{|l|}{ Future 2 (2041-2070) } \\
\hline Maize/spring grain cereals & 5663 & 6173 & 6161 & 6385 & 6455 & 6451 & 295 & 147.0 & 2.3 \\
\hline Wheat/winter grain cereals & 1654 & 1935 & 2090 & 2134 & 2146 & 2196 & 261 & 99.8 & 4.8 \\
\hline Grain legumes & 244 & 294 & 338 & 317 & 290 & 357 & 66 & 28.4 & 8.9 \\
\hline Spring fodder & 3797 & 4143 & 4092 & 4297 & 4349 & 4344 & 257 & 119.3 & 2.8 \\
\hline Winter fodder & 1654 & 1935 & 2090 & 2134 & 2146 & 2196 & 261 & 99.8 & 4.8 \\
\hline Sunflower/oleaginous & 3349 & 3739 & 3800 & 3924 & 3983 & 3966 & 244 & 107.5 & 2.8 \\
\hline Horticulture & 5647 & 6168 & 6142 & 6381 & 6452 & 6436 & 309 & 149.2 & 2.4 \\
\hline Pastures & 4978 & 5543 & 5673 & 5849 & 5903 & 5948 & 405 & 170.1 & 2.9 \\
\hline Fruit orchards (except citrus) & 5128 & 5685 & 5761 & 5928 & 6011 & 6016 & 331 & 150.1 & 2.6 \\
\hline Citrus & 4225 & 4731 & 4927 & 5060 & 5094 & 5114 & 383 & 159.9 & 3.2 \\
\hline Olive groves & 1441 & 1690 & 1741 & 1861 & 1880 & 1888 & 198 & 90.2 & 5.0 \\
\hline Grapevine & 2916 & 3279 & 3279 & 3422 & 3465 & 3458 & 186 & 93.9 & 2.8 \\
\hline Other: golf courses & 4978 & 5543 & 5673 & 5849 & 5903 & 5948 & 405 & 170.1 & 2.9 \\
\hline
\end{tabular}

spread from the median values within each of the 30 year periods considered.

The most irrigation demanding crops such as maize, citrus, fruit orchards and permanent pasture showed a higher range of variation in irrigation requirements between CCS as a response to progressively adverse climate change. In future period 1 (2011-2040), citrus, fruit orchards and maize have the highest variation range of annual irrigation requirements, with, respectively, 213, 186 and $162 \mathrm{~m}^{3} \mathrm{ha}^{-1}$ outlining the high dependency of these crops on irrigation. In future period 2 (2041-2070), these water demanding crops maintained a higher irrigation requirements range between CCS, despite the pasture having the highest variation range $\left(405 \mathrm{~m}^{3} \mathrm{ha}^{-1}\right)$. These results show that the permanent crops, due to requiring irrigation during most of their crop cycle in order to meet their maximum potential yield, can respond with a more steeply increase in irrigation requirements under decreasing rainfall and warmer conditions in comparison with crops with higher demands but with shorter crop cycles such as maize.

Crops such as wheat, sunflower, and winter/spring fodder displayed a more mild behaviour as their irrigation requirements variation pattern lie between crops well adapted to the Mediterranean climate and crops heavily dependent on irrigation.

Fig. 4 depicts the net irrigation requirements variation for each crop type between the climate conditions generated for future 1 (2011-2040) and future 2 (2041-2070) under the influence of different thresholds of warming and rainfall decrease described for each CCS. These results imply that crop irrigation demand variations can respond very differently within crops when given identical variations of the climate variables.

Olive groves and grapevines have the lowest variation between the two future periods analysed, but also have smaller differences between CCS confirming their good adaptation to Mediterranean climate conditions. These crops can be maintained even under harsher conditions resulting from the CCS thresholds considered.
Permanent pasture, citrus and fruit orchards can experience an annual variation above $400 \mathrm{~m}^{3} \mathrm{ha}^{-1}$ in net irrigation requirements between the two 30 year future periods, thereby revealing that climate change has a considerable impact in maintaining these crops at their maximum potential yield conditions.

\subsection{Gross irrigation requirements}

Gross irrigation requirements were estimated in order to mingle the different effects of climate change combinations integrated in the CCS thresholds of progressive rainfall decrease and temperature increase and a set of the most probable alternative irrigated crop area distributions defined as agricultural scenarios.

The total irrigation requirements outputs are shown in Fig. 5 for each combination of CCS and AGS during the two considered future periods (futures 1 and 2). The shape of the output graphics is similar between the agricultural scenarios shown in Fig. 5 (a) AGS-Present, (b) AGS-A, (c) AGS-B and (d) AGS-C, as irrigation requirements for each CCS are driven by common time-based ETo and rainfall data, while the represented irrigation volumes are more closely dependent on the crop distribution and the different irrigated areas defined for each AGS.

Extreme values, averages and range of total irrigation requirements (difference between the maximum and minimum values) are very important, at basin scale, in setting up dam and irrigation network systems management and control. Table 8 summarizes the total irrigation requirements estimated for the Guadiana river basin, outlining the outputs for each combination of future period, climate change scenario and agricultural scenarios.

The agricultural scenario A, representing the complete implementation of the Alqueva irrigation network's projected areas, resulted in total irrigation requirements estimated, for the most representative crops, to be nearly three times higher than the historical agricultural situation for each CCS, reaching a maximum of $875 \mathrm{hm}^{3}$ year $^{-1}$ for the 30-year period (2011-2040) and 


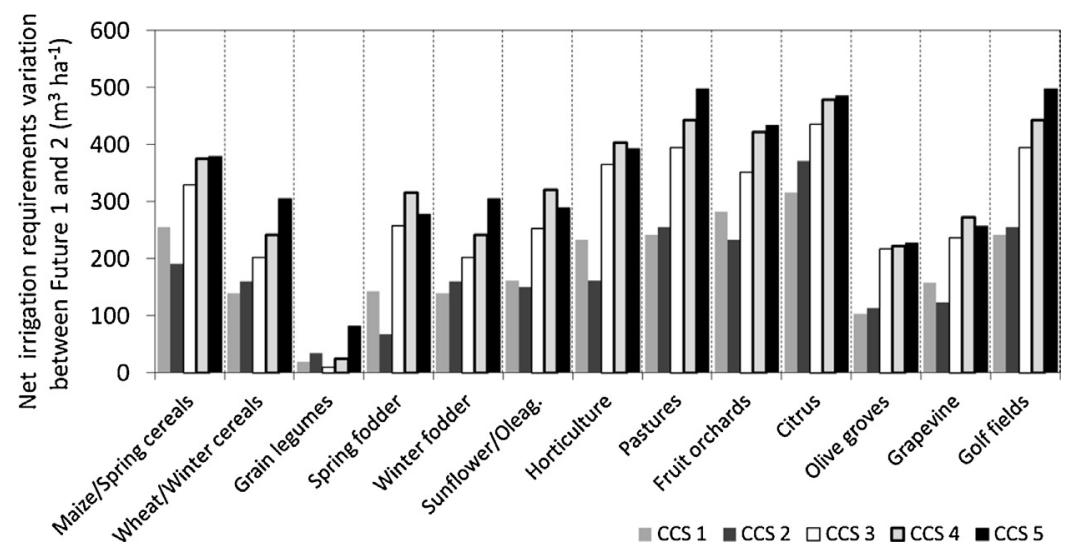

Fig. 4. Net irrigation requirements $\left(\mathrm{m}^{3} \mathrm{ha}^{-1}\right)$ variation between future 1 (2011-2040) and future 2 (2041-2070) for each climate change scenario (CCS).

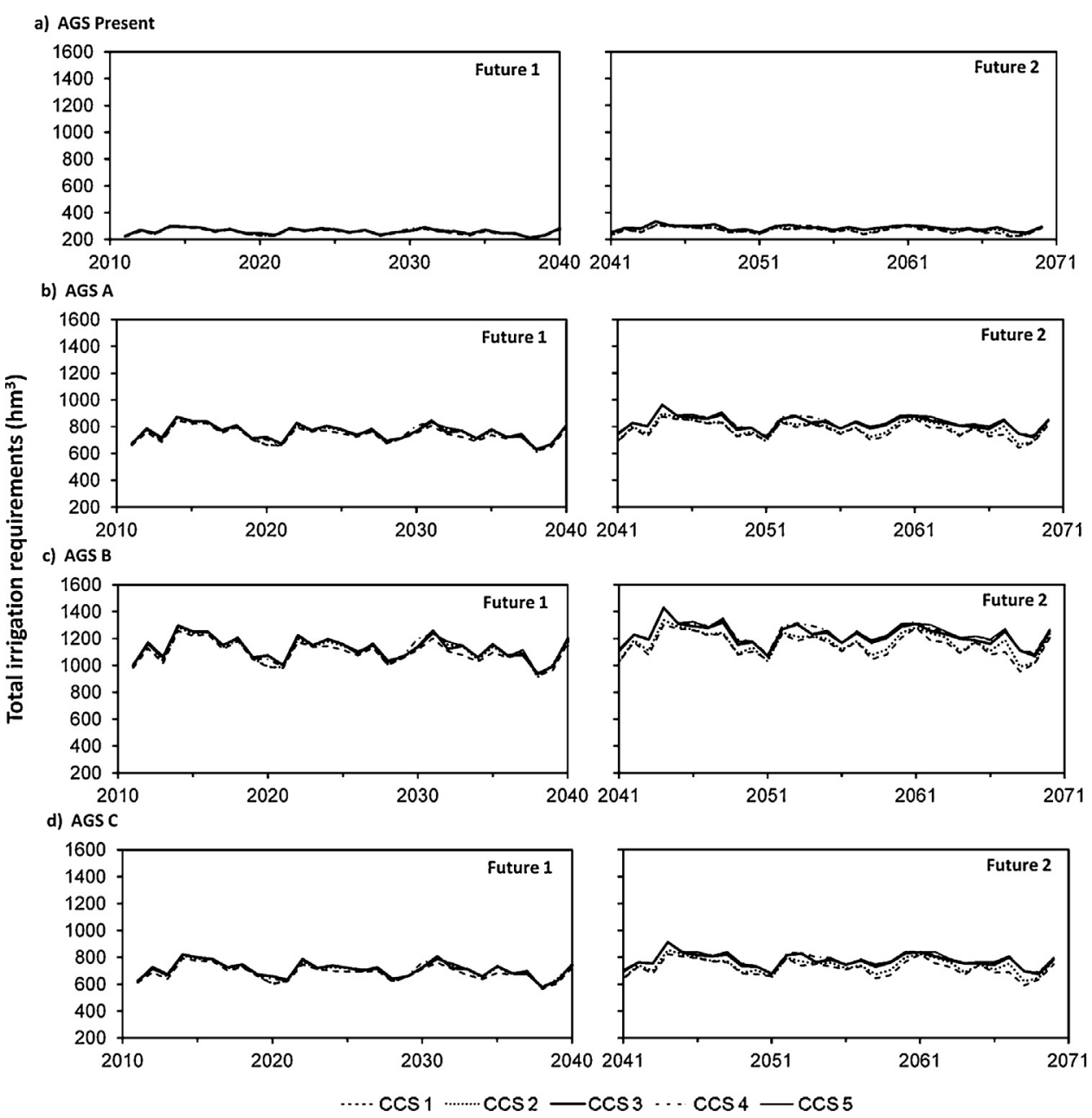

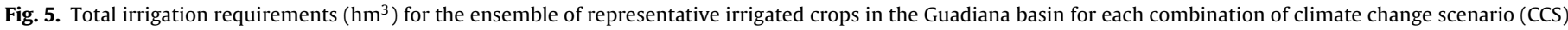
and agricultural scenario (AGS).

$966.8 \mathrm{hm}^{3}$ year $^{-1}$ for future period 2 (2041-2070), both under the most adverse climate change scenario (CCS-5).

For agricultural scenario B, considering the hypothesis that the irrigated area will be increased in $45 \%$ with reference to the new irrigation districts within the Alqueva project, the estimates of total irrigation requirements show a steep increase in comparison with the historical conditions. In this agricultural scenario, and under the CCS-5 climate change thresholds, the total irrigation requirements can reach an estimated maximum of $1300.4 \mathrm{hm}^{3}$ year $^{-1}$ for the period 2011-2040, and $1434.3 \mathrm{hm}^{3}$ year $^{-1}$ for the period 2041-2070. The variation between minimum and maximum (annual range) of annual irrigation total requirements for AGS-B is estimated to be almost as high as the present situation's total maximum requirements, resulting therefore in considerable challenges to management and control of dam water levels and associated irrigation networks.

Under agricultural scenario $C$, the crop distribution was established under the hypothesis that farmers in the future will favour 
Table 8

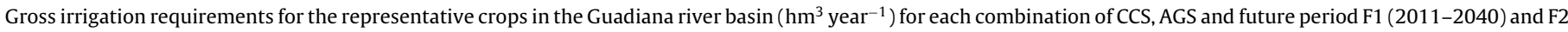

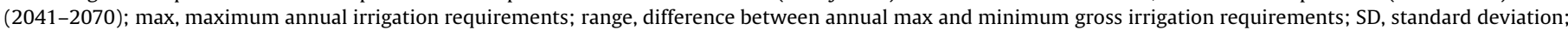

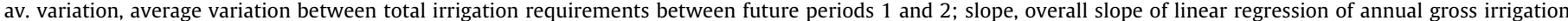
requirements for future periods $\mathrm{F} 1$ and $\mathrm{F} 2$.

\begin{tabular}{|c|c|c|c|c|c|c|c|}
\hline AGS & Period & Total irrigation requirements & CCS-1 & CCS-2 & $\mathrm{CCS}-3$ & CCS -4 & CCS-5 \\
\hline \multirow[t]{10}{*}{ Present } & $\mathrm{F} 1$ & Max & 293.5 & 297.3 & 298.9 & 299.6 & 300.8 \\
\hline & $2011-2040$ & Range & 84.4 & 91.5 & 85.8 & 86.7 & 88.0 \\
\hline & & Average & 253.4 & 258.1 & 260.7 & 261.6 & 261.0 \\
\hline & & $\mathrm{SD}$ & 21.6 & 23.2 & 22.1 & 22.3 & 22.0 \\
\hline & F2 & Max & 303.1 & 309.3 & 333.9 & 335.0 & 335.5 \\
\hline & $2041-2070$ & Range & 83.9 & 84.7 & 86.4 & 82.9 & 83.0 \\
\hline & & Average & 266.7 & 271.6 & 285.5 & 288.2 & 288.3 \\
\hline & & $\mathrm{SD}$ & 22.1 & 22.3 & 19.6 & 19.7 & 19.8 \\
\hline & F2 - F1 & Av. variation & 13.3 & 13.5 & 24.9 & 26.5 & 27.4 \\
\hline & 2011-2070 & Slope & 0.2 & 0.2 & 0.5 & 0.5 & 0.5 \\
\hline \multirow[t]{10}{*}{ A } & $2011-2040$ & Max & 846.4 & 863.8 & 872.8 & 868.2 & 875.2 \\
\hline & & Range & 225.0 & 249.9 & 240.5 & 235.7 & 247.5 \\
\hline & & Average & 736.4 & 750.4 & 758.1 & 759.3 & 758.4 \\
\hline & & SD & 57.2 & 62.1 & 60.2 & 59.9 & 59.7 \\
\hline & $2041-2070$ & Max & 876.0 & 900.5 & 962.6 & 965.6 & 966.8 \\
\hline & & Range & 234.0 & 234.1 & 242.6 & 237.3 & 243.5 \\
\hline & & Average & 773.9 & 787.8 & 823.9 & 834.1 & 833.5 \\
\hline & & SD & 59.7 & 59.9 & 53.8 & 53.8 & 55.0 \\
\hline & $\mathbf{F} 2-\mathbf{F 1}$ & Av. variation & 37.5 & 37.5 & 65.8 & 74.8 & 75.0 \\
\hline & 2011-2070 & Slope & 0.5 & 0.6 & 1.2 & 1.5 & 1.5 \\
\hline \multirow[t]{10}{*}{ B } & $2011-2040$ & Max & 1255.2 & 1283.5 & 1297.0 & 1290.1 & 1300.4 \\
\hline & & Range & 332.3 & 371.1 & 357.9 & 350.5 & 368.2 \\
\hline & & Average & 1093.1 & 1113.8 & 1125.2 & 1127.1 & 1125.8 \\
\hline & & SD & 84.6 & 92.0 & 89.2 & 88.6 & 88.4 \\
\hline & $2041-2070$ & Max & 1301.6 & 1337.7 & 1428.4 & 1432.6 & 1434.3 \\
\hline & & Range & 348.0 & 348.1 & 359.9 & 350.5 & 359.5 \\
\hline & & Average & 1148.6 & 1169.4 & 1222.7 & 1237.9 & 1237.1 \\
\hline & & SD & 88.5 & 88.8 & 79.8 & 79.6 & 81.2 \\
\hline & $\mathbf{F} 2-\mathbf{F 1}$ & Av. variation & 55.6 & 55.6 & 97.5 & 110.8 & 111.3 \\
\hline & 2011-2070 & Slope & 0.7 & 0.9 & 1.8 & 2.2 & 2.2 \\
\hline \multirow[t]{10}{*}{ C } & $2011-2040$ & Max & 791.8 & 813.9 & 820.8 & 813.0 & 823.1 \\
\hline & & Range & 227.6 & 247.3 & 240.6 & 232.5 & 250.8 \\
\hline & & Average & 684.0 & 700.8 & 707.3 & 707.7 & 706.7 \\
\hline & & $\mathrm{SD}$ & 55.9 & 61.4 & 59.6 & 58.7 & 59.0 \\
\hline & $2041-2070$ & Max & 823.1 & 854.1 & 912.6 & 916.1 & 916.8 \\
\hline & & Range & 232.7 & 232.3 & 237.6 & 234.9 & 236.7 \\
\hline & & Average & 720.5 & 739.4 & 773.4 & 782.4 & 782.8 \\
\hline & & SD & 59.2 & 59.2 & 53.4 & 52.7 & 54.4 \\
\hline & F2 - F1 & Av. variation & 36.5 & 38.6 & 66.1 & 74.7 & 76.1 \\
\hline & 2011-2070 & Slope & 0.5 & 0.7 & 1.3 & 1.5 & 1.6 \\
\hline
\end{tabular}

the growing of crops well adapted to Mediterranean climate such as olive groves, and endorse the substitution of high water demanding herbaceous crops such as maize for traditionally rainfed herbaceous and woody crops, in order to increase the productivity of the irrigation water. Agricultural scenario $\mathrm{C}$ also aims to promote soil and water conservation and to reap benefits from the most efficient irrigation methodologies associated with woody crops (drip irrigation versus sprinkler irrigation), assuming future increasing environmental strengthens reflected on water prices. Although assuming a total irrigated area similar to AGS-A, under the most adverse CCS, the results for AGS-C show an estimated maximum total annual irrigation requirements of $823.1 \mathrm{hm}^{3}$ year ${ }^{-1}$ and $916.8 \mathrm{hm}^{3}$ year $^{-1}$, respectively for future periods 1 and 2 . No significant changes were found in the annual ranges of total irrigation requirements between AGS-A and AGS-C as well as in their standard deviations and trends between the two future periods.

The results of AGS-C were partially hampered, because swapping large areas of herbaceous crops for woody crops may not provide significant benefits in minimizing water consumption, as citrus and fruit orchards have shown to respond to climate change with strong increases in water usage (Table 7). This fact limits the potential advantages of replacing typical sprinkler irrigated crops with drip irrigated crops.
The outputs of all future agricultural scenarios (AGS A, B and C) show that total irrigation water demand will likely be significantly displaced towards the public sub-sector after the completion of the Alqueva irrigation network, resulting in a relative increase of water demand in the public sub-sector between 30\% and $32.5 \%$ when compared with the Present scenario. It also looks reasonable to admit that the usage of groundwater resources for irrigation in the Guadiana basin will maintain a complementary but important role in irrigated agriculture, mainly in smaller farms.

\section{Conclusions}

Climate change will cause substantial impacts on water requirements for irrigated agriculture in the Guadiana river basin. Future water and irrigation management decisions can depend on the correct identification of such potential climate change consequences on irrigation requirements. Although no general tendency for variation of ETo was identified in the present study, a general increase in net irrigation requirements of the main representative crops was identified for the five different climate change scenarios studied (CCS 1-5) and future periods 1 (2011-2040) and 2 (2041-2070).

Each crop responded in a different way, depending on the relationships, modelled by the ISAREG programme, of each growing 
stage and respective water requirements interacting with varying temperatures (and ETo) and decreasing rainfall. The crops which are well adapted to the Mediterranean climate, such as olive trees and grapevine, showed less variation in irrigation requirements under adverse climate change, indicating that the induced changes in the rainfall and air temperature do not produce significant changes in these crops estimated irrigation requirements. High water demand crops such as maize and fruit trees (citrus and others) were the crops most prone to significant increases in irrigation demands. The results also showed that herbaceous permanent crops, such as pasture and golf lawn, tended to respond more steeply under adverse climate change conditions, increasing their irrigation requirements and resulting in a higher annual variation than other short-cycle crops.

Gross annual irrigation requirement for agricultural scenario A (AGS A) is $875.2 \mathrm{hm}^{3}$ year $^{-1}$ for the period 2011-2040 and $966.8 \mathrm{hm}^{3}$ year $^{-1}$ for the period 2041-2070, under the most adverse climate scenario (CCS 5).

The results for agricultural scenario B (AGS B) indicate a steep increase of total irrigation requirements, and, under the most adverse climate change scenario (CCS-5), the total estimated irrigation requirements totalled $1300.4 \mathrm{hm}^{3}$ year $^{-1}$ in the period 2011-2040, and $1434.3 \mathrm{hm}^{3}$ year $^{-1}$ in the period 2041-2070. The inter-annual variations in total irrigation requirements for AGSB can reach $368.2 \mathrm{hm}^{3}$ year $^{-1}$ for CCS-5 in the 2011-2040 period, which is higher than the historical total irrigation requirements for the Guadiana basin.

Agricultural scenario C (AGS C) showed similar results to scenario $A$, as the irrigated areas considered for both scenarios are equal. In fact, the swapping of herbaceous crops such as maize and fodder by woody crops did not cause a significant reduction in the overall crop water demand estimates. The substitution of maize and other spring cereals for wheat and other winter cereals with complimentary irrigation may be more effective in saving irrigation water, holding cereal yields on the years with drought and abnormally dry periods. Although olive trees showed a relatively modest increase in water use under climate change, fruit trees (citrus and other fruit orchards) have shown higher values due to its intrinsically unfavourable response to climate change.

The agricultural scenarios elaborated in this study demonstrate that crop area distribution and crop choice can be the most important factor in water use in irrigated agriculture. If properly managed, that choice of area and factors is an important means of promoting conservative and sustainable water use at the basinscale. Therefore, it should deserve the maximum attention from planners and managers, who should take into account the present results when managing water resources in the Alentejo region, in particular the Guadiana basin. More specifically, gross irrigation requirements shown in Table 8 , coupled with estimated urban and industrial uses (mainly power generation) allow for the conclusion that AGS A and C have high possibility to be sustainable, at the pace that AGS B strongly risks to be unsustainable, mainly in drought years which, on the other hand, show an increasing frequency in the future.

These conclusions may apply to all irrigated agriculture subsystems: public, private with surface reservoirs, private pumping from aquifers. However, some constraints referred to AGS B are more likely to occur in the public irrigation sector, because public large reservoirs support, cumulatively with delivering water for irrigation, urban and industrial consumption, as well as water delivery for power generation.

This study provided a quantitative approach for estimating and quantifying the possible water demand outcomes of irrigated agriculture in the Guadiana river basin. However, it is important to underline that future outcomes are also dependent on management practices and soil quality preservation (as considered in AGS-C). The intensification of irrigation will always demand a more conscientious soil management in order to prevent erosion and salinization and to maintain nutrient balance.

Although this study is focused solely on the irrigated agriculture, recognized as the most water-demanding economical sector of the Guadiana river basin, it is important to bear in mind that climate change consequences on water demand in a future water scarcity scenario go well beyond agriculture, requiring a multidisciplinary team for addressing all aspects of planning, management policy development, monitoring and evaluation enforcement, in order to accomplish an equitable allocation of water resources between allconsuming sectors, including the domestic uses, energy generation and ecological management.

\section{Acknowledgments}

This work has been possible thanks to the Fundação para a Ciência e Tecnologia (FCT) through the research project ref. PTDC/AAC-AMB/115587/2009 "Developing a methodology for integrating the effects of climate change in water resources management applied to a Portuguese river basin", with the participation of the Faculty of Engineering of the University of Porto (FEUP, Project leader), the Institute of Agricultural and Environmental Sciences of the University of Évora (ICAAM-UE), the Operative Centre of Irrigation Technology (COTR), and of researchers from the National Oceanic and Atmospheric Administration (NOAA) and the Bureau of Reclamation, from USA.

\section{References}

Adam, J.C., Lettenmaier, D.P., 2003. Adjustment of global gridded precipitation for systematic bias. J. Geophys. Res. 108, 1-14

Allen, R., Pereira, L.S., Raes, D., Smith, M., 1998. Crop evapotranspiration: guidelines for computing crop water requirements. In: FAO Irrigation and Drainage, Paper No. 56, Rome, Italy, 300 pp.

Botelho, F., Ganho, N., 2010. Dinâmica anticiclónica subjacente à seca de 2004/2005 em Portugal Continental. Departamento de Geografia e Centro de Estudos de Geografia e Ordenamento do Território (CEGOT), Faculdade de Letras, Universidade de Coimbra.VI Seminário Latino Americano de Geografia Física, II Seminário Ibero-americano de Geografia Física.

Bureau of Reclamation, 2009. Climate Change and Hydrology Scenarios for Oklahoma Yield Studies. U.S. Department of the Interior. Bureau of Reclamation, Washington D.C., USA.

Bureau of Reclamation, 2011. West-Wide Climate Risk Assessments: Bias-Corrected and Spatially Downscaled Surface Water Projections. U.S. Department of the Interior. Bureau of Reclamation, Washington D.C., USA.

Clarke, D., 1998. CROPWAT for Windows: User Guide. FAO, Rome.

Corte-Real, J., Sorani, M., Conte, M., 1998. Climate change. In: Mairota, et al. (Eds.), Atlas of Mediterranean Environments in Europe. The Desertification Context. Medalus Project. John Wiley \& Sons, Chichester, ISBN 0-471-96092-6, pp. 34-36, Section 2.3.

Cunha, L.V., Ribeiro, L., Oliveira, R.P., Nascimento, J. 2006. Recursos Hídri$\cos [[$ nl]] Water Resources. Chap. 3 in Santos \& Miranda (editors) Alterações Climáticas em Portugal. Cenários, Impactos e Medidas de Adaptação[[nl]]Climate Change in Portugal. Scenarios, Impacts and Adaptation Measures. Project SIAM II. Gradiva. Lisboa.

Doorenbos, J., Kassam, A., 1979. Yield response to water. In: FAO Irrigation and Drainage Paper No. 33. FAO, Rome.

Doorenbos, J., Pruitt, W.O., 1977. Guidelines for predicting crop water requirements. In: FAO Irrigation and Drainage Paper 24. FAO, Rome.

Droogers, P., Allen, R.G., 2002. Estimating reference evapotranspiration under inaccurate data conditions. Irrig. Drain. Syst. 16 (February (1)), 33-45, http://dx.doi.org/10.1023/A:1015508322413.

EDIA (Empresa de Desenvolvimento e Infraestruturas do Alqueva - Alqueva Development and Infrastructures Company), 2013. http://www.edia.pt

EEA (European Environment Agency), 304 pp. 2012. Climate Change Impacts and Vulnerability in Europe 2012. www.eea.europa.eu

Goodess, C.M., Mariani, L., Palutikov, J.P., Menichim, V., Minandi, G.P., 1998. Estimating Future Climates in the Mediterranean. Section 2.4 in Atlas of Mediterranean Environments in Europe. The Desertification Context. Medalus Project. John Wiley \& Sons, Chichester, ISBN 0-471-96092-6, pp. 38-42.

Hargreaves, G.H., Samani, Z.A., 1985. Reference crop evapotranspiration from temperature. Appl. Eng. Agric. 1, 96-99.

INE (Instituto Nacional de Estatística), 2011. Recenseamento Agrícola de 2009 (2009 Agricultural Inquiries). Lisboa. 
30

P. Valverde et al. / Agricultural Water Management 152 (2015) 17-30

IPCC (Intergovernmental Panel on Climate Change), 2014. Climate Change 2014 Synthesis Report, 133 pp. www.ipcc.ch/

Mairota, P., Thornes, J.B., Geeson, N. (Eds.), 1998. Atlas of Mediterranean Environments in Europe. The Desertification Context. Medalus Project. John Wiley \& Sons, Chichester, ISBN 0-471-96092-6.

Maurer, E.P., Adam, J.C., Wood, A.W., 2009. Climate Model based consensus on the hydrologic impacts of climate change to the Rio Lempa basin of Central America. Hydrol. Earth Syst. Sci. 13, 183-194.

Meehl, G.A., Covey, C., Delworth, T., Latif, M., McAvaney, B., Mitchell, J.F.B., Stouffer, R.J., Taylor, K.E., 2007. The WCRP CMIP3 multi-model dataset: a new era in climate change research. Bull. Am. Meteorol. Soc. 88, 1383-1394.

Pinto, P.A., Braga, R., Brandão, A.P. 2006. Agricultura[[nl]]Agriculture. Chap. 5 in Santos \& Miranda (editors) Alterações Climáticas em Portugal. Cenários, Impactos e Medidas de Adaptação[[nl]]Climate Change in Portugal. Scenarios, Impacts and Adaptation Measures. Project SIAM II. Gradiva. Lisboa.

Ramos, V., Vivas, E., Brekke, L., Maia, R., 2014. Methodology for the development of climate change scenarios and climate inputs to run impacts models. Application to the Guadiana River Basin. In: Proceedings of 3rd IAHR Europe Congress, Porto, Portugal.

Rodríguez Díaz, J.A., Weatherhead, E.K., Knox, J.W., Camacho, E., 2007. Climate change impacts on irrigation water requirements in the Guadalquivir river basin in Spain. Reg. Environ. Change 7, 149-159, http://dx.doi.org/10.1007/ s10113-007-0035-3.

Santos, M., Maia, J., 2005. Calibração da ETo estimada pelo método de Hargreaves e tina evaporimétrica classe A. In: Proceedings of the I Congresso Nacional de Rega e Drenagem, Beja.
Santos, F.D., Miranda, P., 2006. Alterações Climáticas em Portugal. Cenários, Impactos e Medidas de Adaptação - Projecto SIAM II. Gradiva, Lisboa.

Serralheiro, R., Carvalho, M., Corte-Real, J., Toureiro, C., 2010. 1 1 a Fase do Sistema de Previsão e Gestão de Secas (SPGS) - Relatórios 1 a 4, 2009 e 2010. ICAAM, Universidade de Évora.

Shahidian, S., Serralheiro, R., Serrano, J., Teixeira, J.L., Naim, H., Santos, F.L., January 2012. Hargreaves and other reduced-set methods for calculating evapotranspiration. In: Ayse Irmak (Ed.), Evapotranspiration - Remote sensing and Modeling. In Tech Europe, Rijeka, pp. 59-80, ISBN 978-953-307-808-3.

Teixeira, J.L., Pereira, L.S., 1992. ISAREG, an irrigation scheduling model. ICID Bull. 41 (2), 29-48.

Valverde, P., Serralheiro, R., Carvalho, M., Shahidian, S., Rodrigues, C., 2014. Efeitos das alterações climáticas nas necessidades úteis de rega na bacia do Guadiana (Effects of climate change on crop net irrigation requirements in the Guadiana basin). Rev. Recur. Hídricos, Lisboa APRH 35 (1), 53-67, ISSN 0870-1741, doi:105894/rh 35 n1-4.

Vivas, E., Maia, R., 2010. A Gestão de Escassez e Secas Enquadrando as Alterações Climáticas. Rev. Recur. Hídricos, Lisboa 31 (1), 25-37, Março, APRH, ISSN 08701741.

Vivas, E., Silva, C., Correia, L., Maia, R., 2010. Definição de unidades de análise para prevenção, avaliação e gestão de situações de seca. Aplicação ao caso da bacia do rio Guadiana, em Actas da Conferência $10^{\circ}$ Congresso da Água - Marcas d'Água, Algarve, Março de 2010 , ISBN 978-972-99991-9-2.

Wood, A.W., Leung, L.R., Sridhar, V., Lettenmaier, D.P., 2004. Hydrologic implications of dynamical and statistical approaches to downscaling climate model outputs. Clim. Change 62, 189-216. 